Chirurgia (2017) 112: 566-572

No. 5, September - October

Copyright $\odot$ Celsius

http://dx.doi.org/10.21614/chirurgia.112.5.566

\title{
The Future of Emergency Surgery
}

\author{
Yan Mei Goh', Parveen Vitish-Sharma'1, Ahmed Saad', Saira Bibi', Peep Talving², Luca Ponchietti' \\ 'Department of General Surgery, Milton Keynes University Hospital, Standing Way, Eaglestone, Milton Keynes, United Kingdom \\ ${ }^{2}$ Institute of Clinical Medicine, Department of Surgery, University of Tartu, Tartu, Estonia
}

Corresponding author: Yan Mei Goh, MD

1504, 3 Merchant Square, Harbet

Road, London, W2 1BF

E-mail: yanmei.goh@doctors.org.uk

\section{Rezumat}

\section{Viitorul chirurgiei de urgență}

Introducere: Pe parcursul ultimelor 3 decenii a existat o nevoie recunoscută pentru chirurgie de urgență (ES). Studiile asupra ES au demonstrat variații ale rezultatelor pacienților în funcție de momentul sau ziua internării. ES ca specialitate este încă pe lista specialităților de luat în considerare în Europa, deşi în SUA a fost deja recunoscută ca atare. Lucrarea de față evaluează această necesitate şi abordează problemele legate de dezvoltarea chirurgiei de urgență ca subspecialitate chirurgicală separată în Europa.

Metodă: Un sondaj privind chirurgia de urgență a fost elaborat de către Comitetul Educațional al Societăți Europene de Chirurgie Traumatică şi de Urgență (Educational Committee of the European Society for Trauma and Emergency Surgery - ESTES) şi trimis tuturor membrilor ESTES, primindu-se înapoi 102 răspunsuri.

Rezultate: Dintre răspunsuri, $93,1 \%$ au provenit de la chirurgi care şi-au încheiat pregătirea. 75,3\% dintre persoanele care au răspuns semnalează că ES ar trebui recunoscută ca subspecialitate, iar $79 \%$ afirmă că ES ar putea oferi o carieră merituoasă. 90\% afirmă că ES ar trebui să beneficieze de programe de pregătire postuniversitare, $69,8 \%$ fiind de acord că medicii chirurgi dedicați chirurgiei de urgență prezintă rezultate îmbunătățite după ES.

Concluzii: Dezvoltarea chirurgiei de urgență ca subspecialitate în Europa ar îmbunătăți rezultatele pacienților şi alocarea resurselor. Acest demers este, însă, abia la început, iar continuarea sa ar necesita revizuirea generală a sistemului european actual, a metodelor de training şi a înțelegerii rolului chirurgilor în chirurgia de urgență.

Cuvinte cheie: chirurgie de urgență, subspecializare, efectul Ringlemann 


\begin{abstract}
Introduction: Over the past three decades, there has been a recognised need for emergency surgery (ES). Studies of ES have demonstrated variation in patient outcomes depending on admission time or day. ES as a subspecialty is still under consideration in Europe despite being recognised as such in the US. This article reviews this need and addresses the issues required to develop ES as a separate surgical subspecialty in Europe.

Method: A survey on ES was developed by the Educational Committee of the European Society for Trauma and Emergency Surgery (ESTES) and sent to all ESTES members with 102 responses received.

Results: Of the responses, 93.1\% had completed training. $75.3 \%$ of respondents report that ES should be a recognised subspecialty and $79 \%$ report that ES is capable of offering a rewarding career. $90 \%$ report that ES should have dedicated post-graduate training programme with $69.8 \%$ in agreement that dedicated emergency surgeons have improved outcomes following ES.

Conclusion: Developing ES as a subspecialty in Europe would improve patient outcomes and facilitate resource allocation. This advancement is, however, still in its infancy and its evolution would require overhaul of our current European system, training methods and understanding of the role of emergency surgeons in ES.
\end{abstract}

Key words: emergency surgery, subspecialisation, ringlemann effect

\section{Introduction}

Emergency Surgery (ES) or Acute Care Surgery (ACS) are the terms being used to designate the operative and medical management of acutely ill surgical patients coming to the hospital with unscheduled insults from a variety of mechanisms including trauma, burns, an acute condition in the abdomen, or necrotising soft tissue infection (1). Over the past three decades, there has been a recognised increase in need for dedicated emergency surgeons $(2,3)$. This is due to a variety of factors including: increase in population age; financial pressures; fewer doctors in training; increased specialisation; 24/7 consultant delivered care; tensions between service delivery pressures and provision of training opportunities; lack of board certification in trauma; heavy amount of night work; and lack of elective schedule $(4,5)$.

Studies and reviews of emergency services in the United Kingdom (UK) has demonstrated variation in outcomes for patients depending on the time of day or day of the week patients are admitted to hospital as an emergency (6-10). This is attributed to reduced service provision; level of consultant involvement; access to diag- nostic imaging and consultant reporting; and pressure in staffing surgical services (11). In light of these pressures, the National Emergency Laparotomy Audit (NELA) was set up to enable the improvement of quality of care of patients undergoing an emergency laparotomy (12). Following this, the Royal College of Surgeons England published guidance on standards for unscheduled surgical care (13). As a result of this, recommendations were developed with attention directed at organisational changes to achieve these standards of care in the UK. These recommendations included: surgical review of acutely unwell patients within 30 minutes of referral; discussion and review of high-risk patients by a consultant surgeon within four hours; direct consultant surgeon supervision and presence in 'high risk' patients; and review of all emergency surgical admission within 12 to 24 hours of admission (13).

Following these recommendations, the role of emergency surgeons in the UK has become increasingly important although ES has yet to be recognised in in the UK and on the European continent. Hence, this article aims to address the need for specific ES training, necessity for autonomous services 
and need for cross-service relationships between different sub-specialities.

\section{Training in Emergency Surgery}

ES services and their impact on mortality and morbidity is well published and is now increasingly recognised (14) and acknowledged by surgeons worldwide. Despite this, ES training as a separate entity to date is still not recognised by the Colleges or Medical bodies in Europe. In the United States, howevet, there seems to be a consensus on the role of ES as a separate entity. This is reflected by their development of a training programme suited to their needs (15-17). The role of the ES in the European Union has yet to be fully developed and/or utilised. This is likely to be due to the significant overlap between emergency and elective services, financial pressures and the current classical training systems in European countries (18). Clinicians who have elected to subspecialise electively are also likely to want to continue on ES pathways to maintain generalised skills (19).

In the European continent, ES training continues to be a large part of training and basic general skills, irrespective of the chosen subspecialty. Not only this, there is also a clear lack of uniformity of surgical training in the European Union and the different specialties under which trauma and emergency patients are admitted (Table 1). As such, potential for trainees to concentrate and continue on ES training may be difficult. Potential advantages of subspecialising in ES include: working in an exciting and challenging field of surgery; enjoyment and job satisfaction; availability and emphasis of trauma in training; academic trauma interest; requirement for involvement in emergency and trauma in clinical practice (5). Meanwhile, disadvantages of participating and specialising in ES from a trainee's perspective include: irregular hours; inadequate operative practice due to a preponderance of blunt trauma; interference with elective practice; exposure to malpractice and poor reimbursement. Personal and lifestyle issues are also important factors that need to be taken into account when choosing to subspecialise in ES (20).

ES services in the UK have changed since the publication of the RCS England Emergency Surgery 'Standards for unscheduled surgical care'. The publication of this document has had an impact the role of the emergency surgeon. Hospitals have gradually evolved to comply with local and national policies and service requirements. Despite a clear discrepancy in the role of the emergency surgeon in different units, local hospitals and NHS trusts have been vying for an increase in the number of emergency surgeons. Whilst ES continues to not be regarded as a sub-speciality in the UK, it is clear that in time, more guidance and the importance of their role in the National Health Service may ensure the development of Emergency and Trauma Surgery as a separate entity, thus forming the 11th surgical subspecialty.

\section{Methods}

In the past decade there has been an increasing need for independence of ES $(2,3)$. Surgeons dedicated to ES are increasing in number; autonomous ES services are blooming in many big hospitals; dedicated sections within National Societies have been created and specific courses have been developed. A survey on ES was developed by the Educational Committee of the European Society for Trauma and Emergency Surgery (ESTES) and sent to all ESTES members $(n=850)$.

\section{Results}

A total of 102 responses were received, of which $64.4 \%$ were between 35 to 54 years and $82.8 \%$ of these respondents were male. All respondents were postgraduate trainees, of which $93.1 \%$ had completed training and $78.2 \%$ were consultants and independently practicing. Of these, $46.1 \%$ were general surgeons, with only $26.5 \%$ identifying themselves as emergency or trauma surgeons. ES is not a recognised speciality in $84.3 \%$ countries and of all 102 respondents, 97.0\% report having ES commitments as part of 
Table 1. The European model: Table to demonstrate the variations in training and provision of emergency services in European Countries

\begin{tabular}{|c|c|c|c|c|c|c|}
\hline & $\begin{array}{l}\text { Orthopaedic } \\
\text { Surgery }\end{array}$ & $\begin{array}{l}\text { Trauma } \\
\text { Surgery }\end{array}$ & $\begin{array}{l}\text { General } \\
\text { Surgery }\end{array}$ & $\begin{array}{l}\text { Cardiothoracic } \\
\text { Surgery }\end{array}$ & $\begin{array}{l}\text { Vascular } \\
\text { Surgery }\end{array}$ & $\begin{array}{l}\text { Emergency } \\
\text { Surgery }\end{array}$ \\
\hline Skeletal Trauma & $\begin{array}{l}\text { Finland, France, } \\
\text { Italy, Norway, } \\
\text { Portugal, Romania, } \\
\text { Spain, Turkey, UK, } \\
\text { Czech Republic, } \\
\text { Germany }\end{array}$ & $\begin{array}{l}\text { Croatia, } \\
\text { Luxembourg, } \\
\text { Netherlands, } \\
\text { Czech Republic, } \\
\text { Germany }\end{array}$ & $\begin{array}{l}\text { Croatia, Luxembourg, } \\
\text { Netherlands, Greece, } \\
\text { Switzerland }\end{array}$ & & & \\
\hline Visceral trauma & & $\begin{array}{l}\text { Czech Republic, } \\
\text { Germany, Slovenia }\end{array}$ & $\begin{array}{l}\text { Austria, Croatia, Finland, } \\
\text { Greece, France, Italy, } \\
\text { Luxembourg, Netherlands, } \\
\text { Norway, Portugal, } \\
\text { Romania, Switzerland, } \\
\text { Spain, Turkey, UK, } \\
\text { Czech Republic, } \\
\text { Germany, Slovenia }\end{array}$ & & & \\
\hline $\begin{array}{l}\text { Abdominal } \\
\text { Emergencies }\end{array}$ & & $\begin{array}{l}\text { Germany, } \\
\text { Netherlands, }\end{array}$ & $\begin{array}{l}\text { Austria, Croatia, Greece, } \\
\text { Finland, Slovenia, Austria } \\
\text { Italy, Luxembourg, } \\
\text { Netherlands, Norway, } \\
\text { Portugal, Romania, } \\
\text { Spain, Switzerland, } \\
\text { Turkey, UK, } \\
\text { Czech Republic, } \\
\text { France, Germany, } \\
\text { Netherlands, Slovenia }\end{array}$ & & & \\
\hline $\begin{array}{l}\text { Thoracic } \\
\text { Emergencies }\end{array}$ & & $\begin{array}{l}\text { Germany, } \\
\text { Netherlands, } \\
\text { Slovenia }\end{array}$ & $\begin{array}{l}\text { Austria, Croatia, Greece, } \\
\text { Italy, Portugal, Romania, } \\
\text { UK, France, Norway, } \\
\text { Spain, Switzerland, Turkey }\end{array}$ & $\begin{array}{l}\text { Czech Republic, } \\
\text { Finland, Austria, } \\
\text { Croatia, Greece, } \\
\text { Italy, Portugal, } \\
\text { Romania, UK, } \\
\text { Germany, } \\
\text { Netherlands, } \\
\text { Slovenia }\end{array}$ & & \\
\hline $\begin{array}{l}\text { Vascular } \\
\text { Emergencies }\end{array}$ & France & $\begin{array}{l}\text { Germany, } \\
\text { Netherlands }\end{array}$ & $\begin{array}{l}\text { Austria, Croatia, Luxembourg, } \\
\text { Portugal, Romania, Slovenia, } \\
\text { Switzerland, Turkey, France, } \\
\text { Norway }\end{array}$ & & $\begin{array}{l}\text { Czech Republic, } \\
\text { Finland, Greece, } \\
\text { Italy, Spain, } \\
\text { UK, Austria, } \\
\text { Croatia, } \\
\text { Luxembourg, } \\
\text { Portugal, } \\
\text { Romania, } \\
\text { Slovenia, } \\
\text { Switzerland, } \\
\text { Turkey, France, } \\
\text { Germany, } \\
\text { Netherlands }\end{array}$ & \\
\hline
\end{tabular}

*UK: United Kingdom

their regular commitments. Nonetheless, ES report that ES should be a recognised subwas provided as an autonomous service in specialty and $79.0 \%$ report that ES is capable $51.0 \%$ of all respondents practice, although of offering a rewarding professional career. $13.9 \%$ of respondents report a Hub and Spoke $90.0 \%$ of respondents report that ES should model and 41.6\% report local ES networks. On have a dedicated post-graduate training direct questioning, $75.3 \%$ of respondents programme, although $80.8 \%$ did report the 
need to retain an elective general surgery practice. There was an agreement by $83.1 \%$ of all respondents that autonomous ES services are required in high volume hospitals, to improve the outcome of patients with acute surgical problems and allow better use of hospital resources. In a similar manner, $69.8 \%$ felt that dedicated emergency surgeons have improved outcomes following emergency procedures although $78.3 \%$ of respondents suggest the need to rely on other subspecialties for more complex cases. ES is reported in $73.5 \%$ to be delivered only by general surgeons (Fig. 1).

\section{Discussion}

Perhaps the only way forward to promote and ensure we have a robust and recognised ES workforce is to come to a consensus within the European Union to create a dedicated ES training with clear recognition of ES as a subspecialty. This in turn could promote develop- ment of a syllabus and assessment of competencies or performance in each training programme, which would be recognised within the EU. It is hopeful that with the current political landscape this change would occur in the foreseeable future.

\section{Autonomous Services}

Multiple studies have shown that emergency surgeon-led trauma services in dedicated units are associated with improved outcomes for ES and trauma patients. In a similar manner, subspecialty outcomes have significantly improved with the advent of dedicated subspecialty services e.g.: colorectal, breast, upper gastrointestinal and hepatobiliarypancreatic subspecialties (21-23). These improved outcomes are likely to be secondary to a combination of improved technical skills and available infrastructure and allied health professional support.

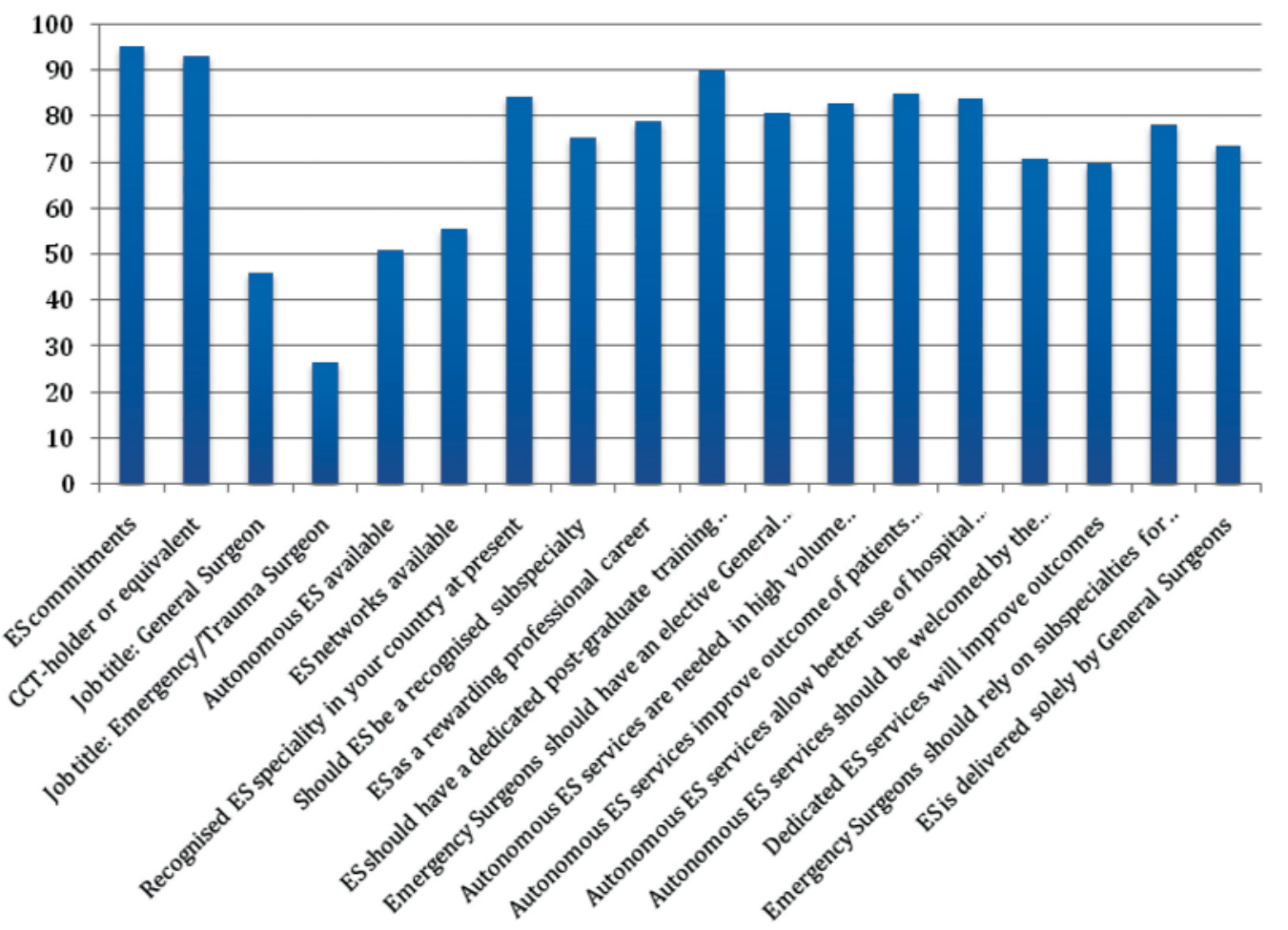

Figure 1. Bar chart demonstrating the results of the survey developed by ESTES 


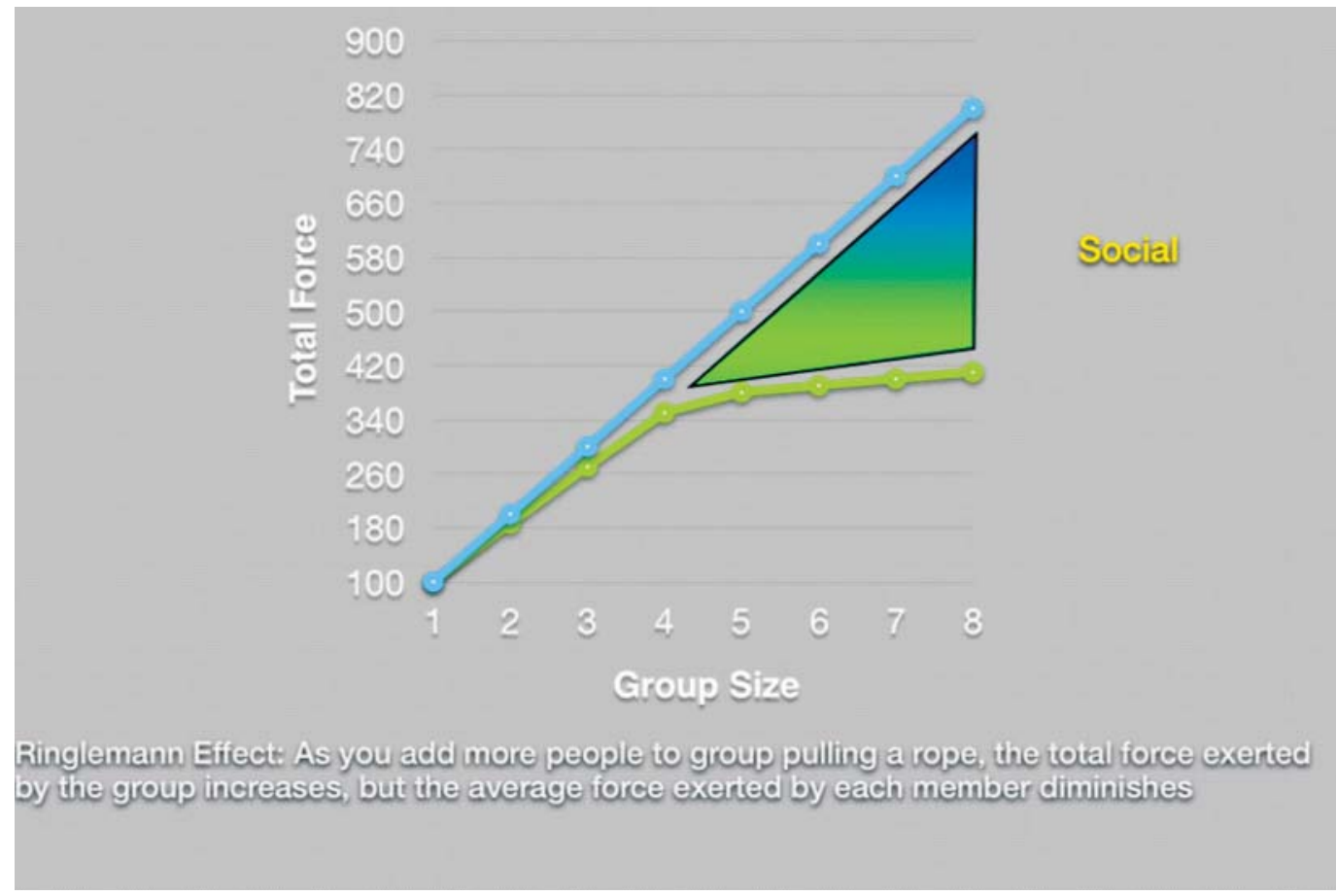

Figure 2. Graph demonstrating the Ringlemann Effect

Maximilien Ringlemann, an agricultural engineer in 1913 while studying the relationship between process loss (i.e., reductions in performance effectiveness or efficiency) and group productivity, identified that having group members work together on a task (e.g., pulling a rope) results in significantly less effort than when individual members are acting alone (Fig. 2). This classic study demonstrates three things: firstly a shared goal is important; secondly the number of individuals working towards the aforementioned-shared goal is equally as important; and lastly improving efficiency in this group implies the need to reduce "loss of motivation" and the "loss of coordination" in the group (Fig. 3). Henceforth, increasing identifiability, minimising freeriding, establishing clear and explicit goals, and increasing involvement are all essential elements to decrease the Ringlemann's effect $(24,25)$. These aspects are the common factors that lead to improved outcomes for surgical subspecialties.

\section{Cross-service Relationships Between Sub-specialities}

Current set up of ES services in the EU are performed as a part of surgeon's regular practice. This poses challenges in the long-term

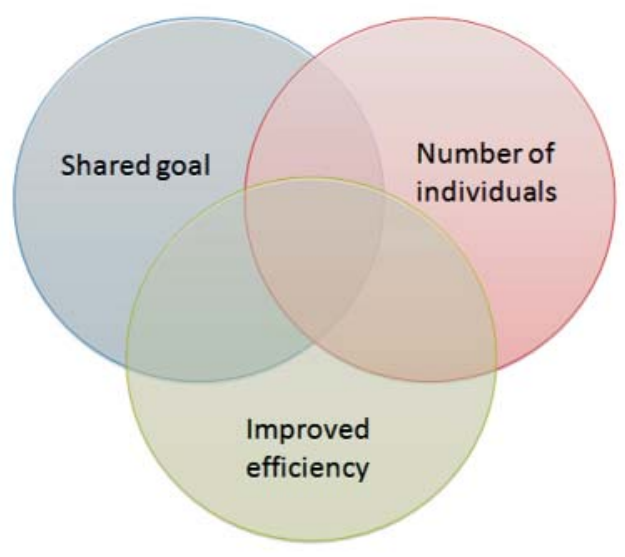

Figure 3. Venn diagram demonstrating inter-relationship between the three pillars that form the foundation of the Ringlemann Effect. 
outcome and management of these patients. Hence, forming ES as a subspecialty by surgeons interested in ES and trauma with support from other subspecialties may help improve overall efficiency, allow smooth allocation of resources in the elective and emergency setting and promote increased autonomy in the emergency subspecialty whilst obtaining further expert advice from other surgical subspecialties.

The utilisation of ES services in an efficient manner should be tailored to each unit's requirements. Given the significant overlap between ES services and elective subspecialties, clear definition of the ES role at present may be difficult. However, perhaps with the continued recognition of ES services and increased understanding of utilisation of emergency surgeons these cross-service relationships can continue to be strengthened and more clearly defined.

\section{Conclusion}

The need to develop ES as separate surgical subspecialty in Europe would bring about significant benefits in patient outcomes and facilitate resource allocation in many units. This development in ES is, however, still in its infancy and its evolution would require significant overhaul of our current classical European system, training methods and cultural understanding of the role of emergency surgeons in ES.

Financial support: None.

\section{Conflicts of interest: None.}

\section{References}

1. Diaz JJ, Miller RS, May AK, Morris JA. Acute care surgery: a functioning program and fellowship training. Surgery. 2007; 141(3):310-6.

2. Shrime MG, Bickler SW, Alkire BC, Mock C. Global burden of surgical disease: an estimation from the provider perspective. The Lancet Global Health. 2015;3:S8-S9.

3. Yi S, Rickard J. Specialization in acute care surgery in low-income and middle-income countries. Trauma Surgery \& Acute Care Open. 2017;2(1):e000095.

4. Watson RA. Challenges and opportunities for emergency general surgery. The Bulletin of the Royal College of Surgeons of England. 2016;98(5):221.

5. Richardson JD, Miller FB. Will future surgeons be interested in trauma care? results of a resident survey. Journal of Trauma and Acute Care Surgery. 1992;32(2):229-35.

6. Aylin P, Yunus A, Bottle A, Majeed A, Bell D. Weekend mortality for emergency admissions. A large, multicentre study. Quality and Safety in Health Care. 2010;19(3):213-7.

7. Bell CM, Redelmeier DA. Mortality among patients admitted to hospitals on weekends as compared with weekdays. New England Journal of Medicine. 2001;345(9):663-8.

8. Barba R, Losa J, Velasco M, Guijarro C, de Casasola GG, Zapatero A. Mortality among adult patients admitted to the hospital on weekends. European Journal of Internal Medicine. 2006;17(5):322-4.

9. Schmulewitz L, Proudfoot A, Bell D. The impact of weekends on outcome for emergency patients. Clinical Medicine. 2005;5(6): 621-5.

10. Ricciardi R, Roberts PL, Read TE, Baxter NN, Marcello PW, Schoetz DJ. Mortality rate after nonelective hospital admission. Archives of Surgery. 2011;146(5):545-51.

11. London N. Adult Emergency Services: Acute medicine and emergency general surgery. Survey of current arrangements: summary of key findings and responses. 2011.

12. The Second Patient Report of the National Emergency Laparotomy Audit (NELA) Standalone Recommendations Document. 2016.

13. Kumar R. Emergency surgery-standards for unscheduled surgical care-guidance by the royal college of surgeons. An audit of current practice in general surgery in a district general hospital. British Journal of Surgery. 2012;99:189.

14. Haut ER, Chang DC, Hayanga AJ, Efron DT, Haider AH, Cornwell EE. Surgeon-and system-based influences on trauma mortality. Archives of Surgery. 2009;144(8):759-64.

15. Reilly PM, Schwab CW, Haut ER, Gracias VH, Dabrowski GP, Gupta $\mathrm{R}$, et al. Training in trauma surgery: quantitative and qualitative aspects of a new paradigm for fellowship. Ann Surg. 2003; 238(4):596-603; discussion 603-4.

16. Davis KA, Jurkovich GJ. Fellowship training in Acute Care Surgery: from inception to current state. Trauma Surgery \& Acute Care Open. 2016;1(1):e000004.

17. Spain DA, Miller FB. Education and training of the future trauma surgeon in acute care surgery: trauma, critical care, and emergency surgery. Am J Surg. 2005;190(2):212-7.

18. Organization WH. Emergency Medical Services Systems in the European Union: Report of an assessment project co-ordinated by the World Health Organization. 2008.

19. Søreide K. Trauma and the acute care surgery model-should it embrace or replace general surgery? Scandinavian journal of trauma, resuscitation and emergency medicine. 2009;17(1):4.

20. Esposito TJ, Leon L, Jurkovich GJ. The shape of things to come: results from a national survey of trauma surgeons on issues concerning their future. Journal of Trauma and Acute Care Surgery. 2006;60(1):8-16

21. Black J. Is increasing subspecialization going to improve surgical care? Surgery (Oxford). 2003;21(1):i-ii.

22. Ng VV, Tytherleigh MG, Fowler L, Farouk R. Subspecialisation and its effect on the management of rectal cancer. The Annals of The Royal College of Surgeons of England. 2006;88(2):181-4.

23. Robson AJ, Richards JM, Ohly N, Nixon SJ, Paterson-Brown S. The effect of surgical subspecialization on outcomes in peptic ulcer disease complicated by perforation and bleeding. World journal of surgery. 2008;32(7):1456-61.

24. Kravitz DA, Martin B. Ringelmann rediscovered: The original article. 1986.

25. Ingham AG, Levinger G, Graves J, Peckham V. The Ringelmann effect: Studies of group size and group performance. Journal of experimental social psychology. 1974;10(4):371-84. 